\title{
Recession, S-Curves and Digital Equipment Corporation
}

\author{
David T. Goodwin and Roger G. Johnson \\ Birkbeck College, University of London \\ Dave.goodwin@gmail.com, rgjedcs.bbk.ac.uk
}

\begin{abstract}
Digital Equipment Corporation (DEC) was founded in 1957 by two MIT engineers. By 1988 it had grown to be the world's second largest computer corporation. From this heady height it took a mere 10 years for the company to disappear completely. This paper looks at DEC both in relation to the S-curve of technology and how it conformed to this model in the first thirty years but missed out on the disruptive technology of PCs and workstations in the late 1980s. Also how they did not see the wave in the late 1990s and missed the opportunity to lead the market once again.
\end{abstract}

Keywords: S-curve, Digital Equipment Corporation, DEC, recession, exemplar.

Michael Mahoney wrote a number of papers ${ }^{1}$ on the History of Computing and one thing he was always urging researchers and historical authors to do was to capture the history of failed computer companies as these are not usually written up and their archives are often destroyed, especially if they are US based. This paper goes some way to realising that goal.

Digital Equipment Corporation (DEC) was founded in 1957 by two MIT research engineers, Kenneth Olsen and Harlen Andersen. They obtained a loan of \$70,000 from ARD one of the first venture capital companies, led by General Georges Doriot. Olsen created the business plan from books he had read and this plan is now housed in the Ken Olsen archives at Gordon College along with many of Olsen's memos. DEC was the jewel in the crown for ARD, making it more than $\$ 355$ million. In its first thirty years DEC became the second largest computer manufacturer worldwide. However over the next ten years it declined spectacularly to be taken over by a PC manufacturer. The reasons for its decline are multiple and interrelated as opposed to Schein's [1] straightforward view that it was the lack of the money gene in DEC management and its cultural DNA that brought about its downfall. Certainly, Olsen was not driven by profit, he was driven by technical excellence which defined the company direction.

DECs early history is not one without its problems, it had to survive a number of trying times as competitors rose to challenge its traditional markets. It also had to resist a number of takeover attempts from companies such as A T \& T. Each time DEC emerged a stronger company except for the final time. Their growth can be linked to disruptive technology, the 'S-curve' and also to the world's financial 'wave'. The world went through four recessions and the US six, including one double-dip in the

\footnotetext{
${ }^{1}$ http://www.princeton.edu/ mike/computing.html accessed Nov 2009.
} 
early 1980s, since the DEC was founded to the time that DEC was sold to Compaq. The data in table 1 is from the National Bureau of Economic Research (NBER). The NBER is considered the official arbiter of recessions, but

"the NBER does not define a recession in terms of two consecutive quarters of decline in real GDP. Rather, a recession is a significant decline in economic activity spread across the economy, lasting more than a few months, normally visible in real GDP, real income, employment, industrial production, and wholesale-retail sales",2.

Table 1. Recessions of DEC period generated from NBER data ${ }^{3}$

\begin{tabular}{|l|l|l|l|}
\hline \multicolumn{1}{|c|}{ Date } & Duration & $\begin{array}{c}\text { Time since last } \\
\text { recession }\end{array}$ & $\begin{array}{c}\text { Peak } \\
\text { unemployment }\end{array}$ \\
\hline Aug. 1957-April 1958 & 8 & 39 months & $7.5 \%$ \\
\hline April 1960-Feb. 1961 & 10 & 24 months & $7.1 \%$ \\
\hline Dec. 1969-Nov. 1970 & 11 & 106 months & $6.1 \%$ \\
\hline Nov. 1973-March 1975 & 16 & 36 months & $9.0 \%$ \\
\hline Jan. 1980-July 1980 & 6 & 58 months & $7.8 \%$ \\
\hline July 1981-Nov. 1982 & 16 & 12 months & $10.8 \%$ \\
\hline July 1990-March 1991 & 8 & 94 months & $7.8 \%$ \\
\hline
\end{tabular}

Source: NBER

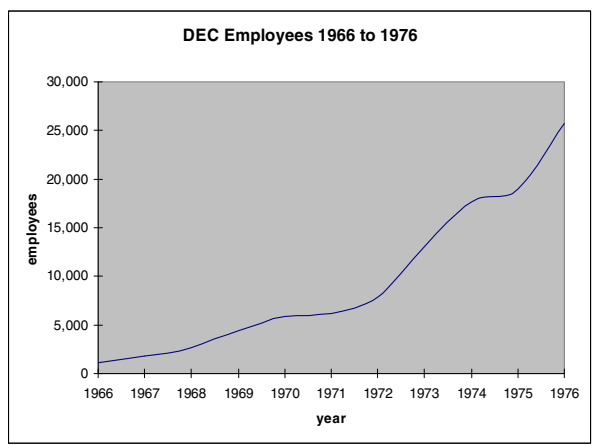

Fig. 1. DEC employees 1966-1976

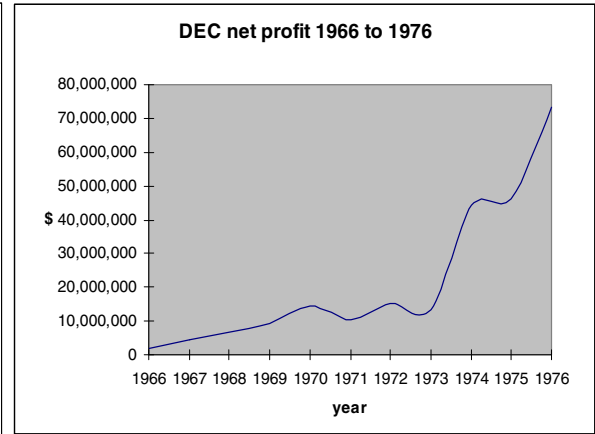

Fig. 2. DEC net profit 1966-1976

There are a number of different recession shapes that occur in literature the most common being V-shaped, U-shaped and W-shaped. DEC suffered, like most other companies, in these recessions but shielded its workers from redundancy by redeployment

\footnotetext{
${ }^{2}$ National Bureau of Economic Research, http://www.nber.org/

${ }^{3}$ National Bureau of Economic Research, http://www.nber.org/cycles/cyclesmain.html
} 
until the late 1980's when economic circumstances and pressure from Wall Street forced it to resort to large scale layoffs. In the 1970, 1973 recessions, DEC reduced its hiring, stabilised its workforce and rode out the recession as can be seen in figure 1 . The result of the recessions on profit during this period is shown in figure 2 and clearly demonstrates the impact of the recessions on the profit of the company and how it impacted growth.

In the recession of the early 1980s it appears that DEC did not apply the same rules on hiring as can be seen in figure 3. This impacted the company in 1983. Ken Olsen said in a speech to the Newmans Society in 1982 that he had said publically " $D E C$ didn't need recessions to straighten us out,' but that it wasn't true, recessions made DEC strong".

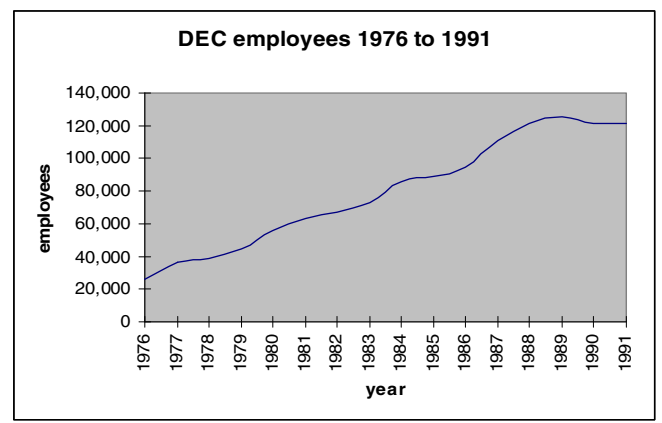

Fig. 3. DEC employees 1976-1991

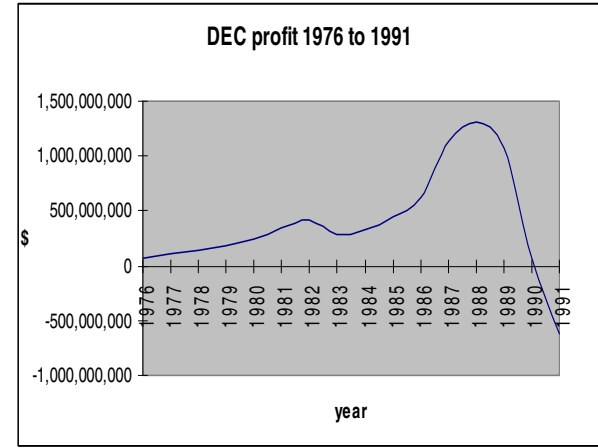

Fig. 4. DEC profit 1976-1991

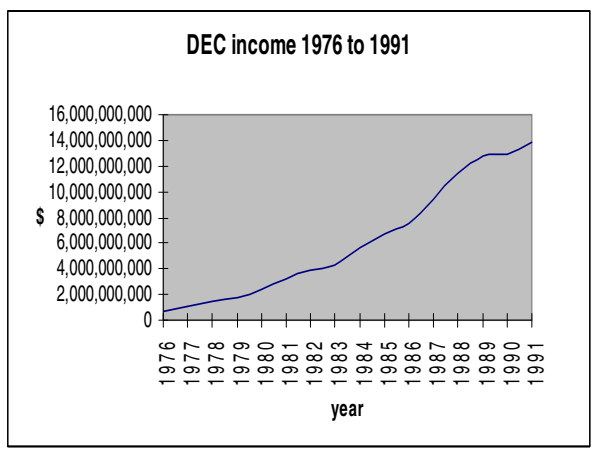

Fig. 5. DEC income 1976-1991

Again, this statement was true up until 1982 when there was no hiring freeze imposed and so expense grew and profits suffered for a number of years as can be seen in figures 4 and 5. In the mid 1980's DEC was forced into staff reductions. The method they used is described in Allen and Scott Morton [2] who did a study of employment security at DEC. It showed how a firm could manage its workforce without enforced redundancies thus maintaining its reputation for employment security. The major proportion of the reduction was in the manufacturing areas, primarily 
in the US. This was a forced reaction to the sudden decline in the stock market value of the company in 1983 when the value of the stock dropped by $29 \%$ in three weeks due to reporting problems within the company. They finally imposed a hiring freeze, retrained 4000 new manufacturing personnel and only had to make 600 redundant as illustrated by Rifkin and Harrar [3]. This was undertaken over a three year period from 1983.

The theory of the S-curve suggests that all businesses follow an S-curve in their development taking a certain amount of time to get to $10 \%$ market share and a similar amount of time to reach $90 \%$. At which point, the company will fade away unless they can re-invent their product/industry and begin a new S-curve. Modus [4] states that:

"The projected life cycle of consumer products and the rate at which substitute products will gain market share is of vital interest to any company". He suggests that "Business, in the form of products, companies and entire industries, goes through five cycles which align with the S-curve".

He also suggests that the S-shaped curve also shows up in other life cycles. For example he states that:

- $\quad$ A product $S$-curve may typically have a life cycle of 6 quarters.

- A product family $S$-curve, consisting of a set of related products, will typically have a life cycle of around 5 years.

- Basic technologies or industry S-curves, consisting of a number of product families and associated companies, typically have a life cycle of approx. 15 years.

DEC followed this cycle successfully for many years. For product life cycles, they released a new major product almost every year from 1965, thus having overlapping S-curves. For family product lifecycles they released the PDP-8 in 1965. The last model in the family was produced in 1979 and they sold over 50,000 systems. There were 10 different models released in the 15 years. This is accepted as the first real minicomputer and heralded the start of affordable computing. Gordon Bell and Ed de Castro are credited as being the main designers of the PDP-8. Five years later in 1970 they followed it with the PDP-11, with the last product in the family being released in 1990. The PDP-11 family, excluding the 32 bit extensions, consisted of at least 23 models and was the leader in the minicomputer market for many years. In 1975 DEC released the $11 / 70$, this was meant to be a stop-gap machine with 1000 planned. Eventually 10,000 were sold. Then, in 1977 the 11/780, DEC's first 32-bit machine, was released. In 1984 the VAX 8600 came out, in 1990 they released the VAX 9000 and finally in 1992 DEC released the 64 bit Alpha family. By the time DEC was taken over by Compaq, the VAX family consisted of around 135 models with the final VAX, in the Alpha range, being manufactured in 2005. These cycles fed DEC's incredible growth over the years.

Christensen [5] looks at technology S-curves and asks how value networks and the concept of S-curves relate to each other. He postulates that disruptive technology does not fall into the normal S-curve as it gets its commercial start in emerging value networks before invading established networks. Clearly DEC had disruptive technology with its minicomputer products, taking the mainframe makers by surprise and creating 
a new market for their product. With the PDP-11 they were forced into the market by Data General, which was formed by three ex-DEC engineers led by Edson de Castro who was disillusioned by DEC's decision not to go ahead with the 16 bit system he had been designing. Having formed Data General he brought a system to market very quickly and forced DEC to respond with their very successful PDP-11 range. In this instance it was Data General who had the disruptive technology that forced a reaction from DEC. De Castro had worked on the design of the PDP-8 and was working on the next system codenamed PDP-X which was to be DEC's 16 bit offering. When he left to start Data General his name was effectively wiped from DECs official histories. The Data General story is told in Tracy Kidders book "the Soul of a New Machine" [6]. In Rifkin's [3] book there is commentary on whether the team that left to form Data General were working on the Nova design whilst at DEC and Olsen is quoted as saying that DEC had a copy of their log of what they were doing for their last two years at DEC.

Looking at base technologies DEC had overlapping S-curves, starting with the PDP-8 family in 1965, the PDP-11 family in 1970 (forced by Data General's release of the Eclipse). The VAX 11/780 released in 1978 and the Alpha in 1992. This was fine when there were base technology overlaps but the Alpha was fourteen years after the VAX 11/780 and so at the limit of the S-curve creating problems for DEC in the area of uptake. This is graphically exposed in the figure 6 which shows the gap in major product release during the 1980's. The effect of this was hidden from the company by good sales of the VAX, the mid life kicker of the VAX 8600 and the sustained economic climate of the 1980s. When the recession came, it hit DEC hard especially as the VAX 9000 was two years late and released when the recession was at its worst.

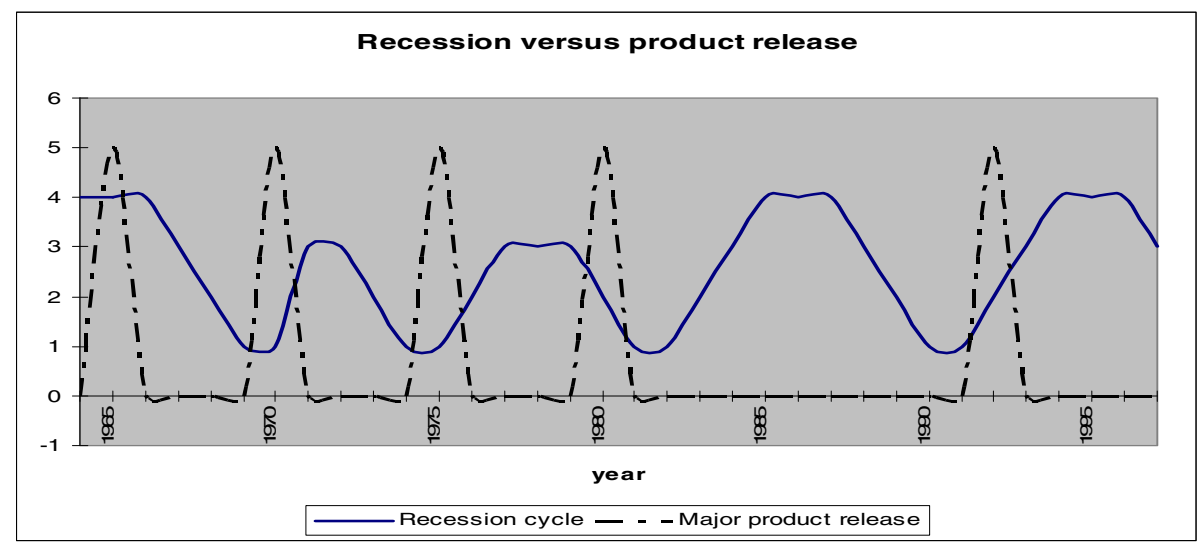

Fig. 6. Recession versus major product release

Asthana [7] looks at S-curves related to disk drive technology and comments that a phenomenon that needs careful S-curve analysis is the moving technology target. Again, this hit DEC in the early 1990s when a major development program should have put them in a leadership position in disk technology. However it took them so 
long to get an acceptable mean time between failure rate of their first thin-film technology disk drive that the competition had released smaller cheaper disks. This was one of the largest development projects in the company history and included a number of new technologies in the one product. DEC made a similar error in the VAX 9000 design where they again introduced three new technologies at once which caused delays in product shipment.

DEC missed two disruptive technologies in the 1980's which could have kept them on the next S-curve. The company missed the advent of the workstation by focussing on the IBM market anticipating the VAX9000 as their IBM killer. This allowed SUN amongst others to take what was once DEC's traditional market. DEC realised very late that the workstation market was important and started a workstation engineering group. This forced them into using a third party chip to challenge the competition and to cancel their own in-house project for a RISC chip codenamed PRISM. This, for a time, gave them a successful workstation and market share but it was short lived as they decided that an in-house chip was needed and started the Alpha project which confused their MIPS customers and led to a loss of marketshare. The other disruptive technology was the PC where DEC tried to create three products to compete in the marketplace when one would have given them a lead had they realised. They set up three competing groups to build a PC, the Robin, running both DOS and CP/M, a proprietary system, the Professional, and a word processing system. The groups didn't appear to know of each others existence and did not use industry standard parts so were not compatible with each other or the IBM PC standard. The sales force were confused as to which was the PC competitor and missed out on sales of the Robin PC by putting the Professional forward as DEC's main offering.

DEC is quoted in Bower and Christensen's article on 'Catching the Wave' [8] as almost completely missing the disruptive technology of the personal computer. They blame arrogance, tired executive blood, poor planning and strangely 'staying close to their customer'. Many however contend that DEC were not in a position to take on the PC market as their processes were aligned to medium volume, high margin products and not the high volume low margin market. Had they recognised the workstation market then there might not have been a crisis of confidence a few years later.

In the mid 1990s there were two other disruptive technologies that DEC had a chance to lead the market with had the company not been fighting for survival and not focussing on building for growth. The first was fast networks linked to the requirements of the internet where DEC was in a lead position in gigabit technology until Palmer sold off the network business in 1977 to concentrate on 'core' products. The second was the internet and all that that brought. DEC was the leader in internet business, forming an internet business unit under Rose Ann Giordano and creating some excellent products. DEC, according to staff interviewed, were aware of the 'wave', DEC management was always talking about riding the wave. However as figure 7 shows graphically they missed the wave of the 1980's, the Alpha S-curve was late in starting and they didn't really get back on track until the internet wave of the mid 1990's. Unfortunately, by this time the board had removed the CEO installing someone who didn't understand the internet and who was in the process of finding a merger/buyer for the company. Had he taken time to look at what was happening in 1997 things might have been different. It is clear that DEC had once again got back 
onto the S-curve and were well placed to ride the next wave. DEC had created Alta Vista in its Western Research Lab as a way to use the power of the Alpha processor and had already established the Alpha as a force in internet business suppliers such as Amazon because of its power. This was mainly on Unix based systems however rather than Open VMS.

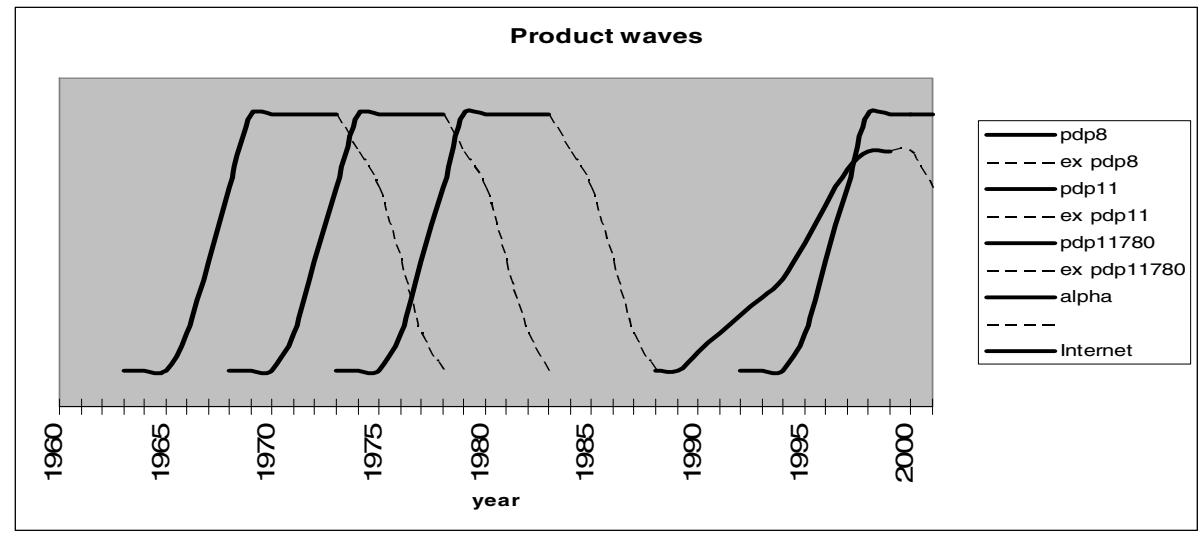

Fig. 7. New product 'waves'

Russ Jones in a chapter of Cronin's book [9] looked at DEC's internet business and its leadership position in late 1994. DEC was the first fortune 500 company to have its own web site when it opened the first commercial home page on the internet in October 1993. They had the majority of the business server market in the internet arena with Amazon as a major customer. When they released AltaVista it was an instant hit and the name went from nothing to worldwide fame in six months being better known than DEC itself. It was the search engine used by Yahoo, cementing its position as search engine of choice. DEC produced the first internet firewall product, the first tunnelling software in 1991 and was well ahead of the competition.

When the founders of Google, Larry Page and Sergey Brin, came to DEC with an offer of joining with AltaVista for $\$ 1$ million, DEC's response was negative due to a 'not invented here' attitude and senior management preparing for the sale of the company. This was certainly another opportunity missed for DEC. Palmer didn't understand what he had in AltaVista. He didn't understand the potential of the internet, valuing AltaVista at $\$ 0$ when the sale to Compaq went through. In 1999 Compaq sold AltaVista to CMGI for $\$ 2.3$ billion. Bell in his appendix to Schein [1] stated that Internet business products were perfect for DEC, they had all the pieces including servers, software and networking, however they didn't understand how to organise to engage in a new market.

DEC, IBM and HP are all exemplars quoted by Peters and Waterman [10] as organisations with structures and strategies that are the ones to follow. Yet by 1990 all three were in deep trouble suggesting that the study by Peters and Waterman [10] was 
in some way inaccurate. In their updated version they add an authors note on Excellence 2003 where they try to justify their publication in terms of excellence value. They totally ignore DEC in this commentary. However a paper written by Crainer and Dearlove [11] analyses the companies in the book ten years later and report that Michelle Clayman found that

'the companies featured in the book beat the stock market by one percent, whereas the mass of unexcellent companies beat the stock market by around $12 \%$ over the five years following the book's publication'.

Sheth [12]( page 4) comments that DEC was a fun place to work and suggest it was no wonder that Peters and Waterman [10] considered DEC as on of the 15 exemplars. However, he goes on to question DECs status at the end of the decade and its late entry into the PC and workstation market, going on the describe the company as one where executives were fleeing, and layoffs, once an abhorrent practice in DEC, were now occurring.

McGrath [13] wrote of the product strategies of high technology companies and has a number of extremely pertinent comments to the situation the DEC found itself in the 90's. He explores the importance of strategy, and the need for changes in strategy as technology changes, the reaction to stagnation of strategy and the potential for diversification. He comments on the selection of Palmer as the CEO and also looks at some of the products that DEC had and their potential for strategic advantage that was not followed up on. He also has commentary on many of the competitive companies at the time and their strategies which either helped them survive or aided their demise. McGrath [13] implies that DEC strategy on the Internet was only developed by Palmer in 1997 which was, in his opinion a few years too late. This was taken from the company report of 1997. However this strategy had been developed a few years earlier within the company. Rose Ann Giordano had been made VP of the Internet Business Group in 1994 to develop the vision and strategy but this was not recognised as strategic by Palmer until later, many saying that he did not understand the value of the Alta Vista product range.

Pettigrew, Thomas and Whittington [14] talk of the diversification index for the Fortune 500 companies declining from 1.0 to 0.67 in the period 1980 to 1990 as divestiture replaced diversification driven by the shifting of corporate goals from growth to profitability and pressure from shareholders and financial markets. This led to the ousting of many CEO's, including Ken Olsen, by increasingly independent boards. The move from diversification appears to go against some of the findings as quoted by Pettigrew, Thomas and Whittington [14] where related diversification linked closely to core business was superior to unrelated diversification.

General Georges Doriot in the address to the Newcomen Society ${ }^{4}$ stated that when you have a strong president your directors should be very peaceful. In fact DEC directors were placid for most of DECs history. Often board meetings were said to be more of a social event than a formal board ${ }^{5}$. The board members were weak according to

\footnotetext{
${ }^{4}$ Digital Equipment Corporation, the First Twenty-five Years, Kenneth Olsen speech to the Newcomen Society, Newcomen Publication Number 1179, Sept $21^{\text {st }} 1982$.

${ }^{5}$ Interview with former board member in Boston, October 2009.
} 
many commentators and most directors, when contacted, were unwilling to talk about their time on the board of DEC. Many did not understand the technology or the business but still made decisions that impacted the company direction. One member that did agree to discuss their time on the board commented that the decision to replace Olsen was not voted on. He also stated that they decided on Palmer without looking outside the company as he appeared to understand the PC business. Their decision was based on videos they had asked senior managers to complete stating what they would do to rescue the company. Palmer took coaching in video techniques prior to recording his video. ${ }^{6}$ Board meetings became increasingly acrimonious once DEC's profits declined and General Doriot died, leaving Olsen isolated. Olsen tried in vain for many years to get his senior managers to give him realistic budgets to give to the board. ${ }^{7}$ In 1992 the board asked for an austerity budget and Olsen asked for a budget for growth. This clash plus a reluctance to cut as many heads as the board had asked for led to the board asking Olsen to leave.

In conclusion, one of the many factors contributing to DEC's downfall was missing the S-curve in the mid 1980s and not having a strategy to recover. They left it too late to move to RISC architecture allowing competitors to capture the workstation market. They were riding the wave during the 1960's and 1970's but their success made them try to get into larger markets rather than their traditional ones. They missed the PC and workstation revolution by focusing on IBM's business and their profits suffered as margins were eroded. However, they could have recovered in the late 1990s had they realised that they were on the next S-curve and a leader in the field of the internet. The Board's decision to select Palmer to succeed Olsen was taken in haste and with little apparent though as to what the company direction should be. He was chosen mainly because the board though Olsen had missed the PC revolution.

\section{References}

1. Schein Edgar, H., DeLisi, P.S., Kampas Paul, J., Sonduck Michael, M.: DEC Is Dead, Long Live DEC: The Lasting Legacy of Digital Equipment Corporation. Berrett-Koehler, San Francisco (2003)

2. Allen Thomas, J., Scott Morton Michael, S.: Information Technology and the Corporation of the 1990s. Oxford University Press, Oxford (1994)

3. Glenn, R., George, H.: The Ultimate Entrepreneur: The Story of Ken Olsen and Digital Equipment Corporation. Contemporary Books, Chicago (1988)

4. Theodore, M.: Conquering Uncertainty: Understanding Corporate Cycles \& Positioning Your Company to Survive the Changing Environment. McGraw-Hill, New York (1998)

5. Christensen Clayton, M.: The Innovator's Dilemma. Harper Collins, New York (2006)

6. Tracy, K.: The Soul of a New Machine. Back Bay Books, Boston (2000)

7. Praven, A.: Jumping the Technology S-Curve. IEEE Spectrum, 49-54 (June 1995)

8. Bower Joseph L., Christensen Clayton M.: Disruptive Technologies; Riding the Wave. Harvard Business Review, 43-53 (January-February 1995)

\footnotetext{
${ }^{6}$ Interview with Olsen's personal assistant October 2009.

${ }^{7}$ Ken Olsen's memos in the Ken Olsen Archives at Gordon College, Massachusetts.
} 
9. Cronin Mary, J.: The Internet Strategy Handbook; Lessons from the New Frontier of Business. Harvard Business School Press, Boston (1996)

10. Tom, P., Waterman Robert Jr., H.: Search of Excellence: Lessons from America's Best Run Companies. Profile Books, London (2004)

11. Crainer, S., Dearlove, D.: Excellence Revisited. Business Strategy Review 13(1), 13-19 (2002)

12. Sheth Jagdish, N.: The Self Destructive Habits of Good Companies: and How to Break Them. Wharton School Publishing, New Jersey (2007)

13. McGrath Michael, E.: Product Strategy for High-Technology Companies: Accelerating your Business to Web Speed. McGraw Hill, New York (2000)

14. Andrew, P., Howard, T., Richard, W.: Handbook of Strategy and Management. Sage Publications, London (2007) 